\title{
DISTRIBUTION, SOURCES AND MODIFIED DEGREE OF CONTAMINATION OF TRACE ELEMENTS IN LINGGI ESTUARY SURFACE SEDIMENTS, MALAYSIA
}

\author{
MD SUHAIMI ELIAS*1,2, SHARIFF IBRAHIM ${ }^{1}$, KAMARUDIN SAMUDING ${ }^{3}$, JEREMY \\ ANDY DOMINIC DAUNG ${ }^{3}$, NESAMALAR KANTASAMY ${ }^{1}$, SHAMSIAH AB RAHMAN ${ }^{2}$ AND \\ AZIAN HASHIM ${ }^{2}$
}

${ }^{1}$ School of Chemistry and Environment, Faculty of Applied Sciences, University Technology MARA (UiTM), 40450, Shah Alam, Selangor, Malaysia. ${ }^{2}$ Analytical Chemistry Application Group (ACA), Waste and Environmental Technology Division, Malaysian Nuclear Agency, Bangi, 43000, Kajang, Selangor, Malaysia. ${ }^{3}$ Environmental Tracer Application Group (E-TAG), Waste and Environmental Technology Division, Malaysian Nuclear Agency, Bangi, 43000, Kajang, Selangor, Malaysia.

*Corresponding author: mdsuhaimi@nm.gov.my

Submitted: 8 September 2019 Accepted: 5 March 2020

http://doi.org/10.46754/jssm.2020.06.011

\begin{abstract}
The purpose of this study is to assess the trace elements of barium (Ba), bromine $(\mathrm{Br})$, cesium $(\mathrm{Cs})$, cobalt $(\mathrm{Co})$, hafnium $(\mathrm{Hf})$, iron $(\mathrm{Fe})$, manganese $(\mathrm{Mn})$, rubidium $(\mathrm{Rb})$, scandium (Sc) and vanadium (V) in the surface sediments of Linggi estuary in Negeri Sembilan, Malaysia, using the neutron activation analysis (NAA) technique. Results showed that the average concentration of $\mathrm{Br}, \mathrm{Cs}, \mathrm{Hf}, \mathrm{Rb}, \mathrm{Sc}$ and V were 75.1, 12.6, 10.0, 146, 10.6 and $80.5 \mathrm{mg} / \mathrm{kg}$, respectively, which were all higher than the upper continental crust (UCC) reference values. However, the average concentration values of $\mathrm{Ba}, \mathrm{Co}, \mathrm{Mn}$, and $\mathrm{Fe}$ were $272,6.39,350$, and $26,547 \mathrm{mg} / \mathrm{kg}$, respectively, which were all relatively lower compared to the UCC values of the respective elements. The provenance of $\mathrm{Br}$ and Hf were from seawater and marine organisms, while $\mathrm{Cs}$ and $\mathrm{V}$ came from from anthropogenic activities, such as discharge from electronic factories and vehicle workshops. The element of $\mathrm{Rb}$ and Sc originated from geogenic processes, such as erosion, landslide and weathering. Overall, the trace element contamination in surface sediments of Linggi estuary was categorised as moderate to highly modified degree of contamination $\left(m C_{d}\right)$, and these could result in adverse effects on benthic dwelling organisms and aquatic life.
\end{abstract}

Keywords: Linggi estuary, trace element, concentration, modified degree of contamination.

\section{Introduction}

Estuaries can be efficient traps for suspended matter that are commonly associated with the elements (major and trace metals) and organic compounds (Liu et al., 2018) China. Sediments were analysed for heavy metals $(\mathrm{Hg}, \mathrm{As}, \mathrm{Cd}, \mathrm{Cr}$, $\mathrm{Cu}, \mathrm{Pb}$, and $\mathrm{Zn}$. Contaminant plumes of trace elements are usually conveyed out to sea by rivers, and significant processes of sedimentation will occur in estuaries. The geochemistry processes of trace element accumulation in estuary sediments involve the mixing of suspended sediments (trace element pollution); resuspension of sediments by waves, tidal effects and dredging activities; mobilization and precipitation of sediments in the water column; flocculation and coagulation of sediments; and, adsorption and desorption of sediments due to salinity and/or turbidity effects (Zwolsman \& Eck, 1999).
Studies on sediment elemental pollution due to major, trace and rare earth elements in estuaries and coastal areas of Malaysia are still limited (Looi et al., 2013; Elias et al., 2018a). The sources of trace element contamination in marine and freshwater sediments mainly originate from two sources, namely anthropogenic and geogenic processes. The major activities that contribute to anthropogenic process are sand mining, logging, land clearing, road construction, manufacturing, domestic sewage, crop planting (palm oil and rubber), livestock farming and shipping activities (Yap et al., 2010; Ashraf et al., 2017; Elias et al., 2018a; 2018b). Meanwhile, geogenic process occurs with weathering of soil and rocks, coastal and riverbank erosion, terrestrial runoff and atmosphere deposition (Ashraf et al., 2017; Elias et al., 2018b). 
The Linggi river (Sungai Linggi) is located in the Malaysian state of Negeri Sembilan. From the highlands, it flows past urban and industrial areas around the state capital Seremban, and into the Straits of Malacca at its estuary (Kuala Linggi) near the coastal town of Port Dickson and the neighbouring state of Malacca. It is considered a heavily polluted river and its water quality has been classified as Class III out of five classes by the Department of Environment (DOE, 2006). The discharge of terrigenous substances and plumes upstream, which include heavy, major and trace metals, will eventually pollute its estuary surface sediments. This will bring an adverse impact on the flora and fauna, especially fish, bivalves and benthic dwelling organisms that directly inhabit the sediments (Ashraf et al., 2017).

Anthropogenic (metalworks, electronics, agriculture and mining) and geogenic processes (terrestrial runoff, river and coastal erosion, and weathering) have been identified as the contributors of rare earth elements (REEs), heavy metals and actinides (thorium and uranium) in the surface sediments of Linggi estuary (Elias et al., 2018b). Trace elements of bromine $(\mathrm{Br})$, rubidium $(\mathrm{Rb})$, vanadium $(\mathrm{V})$, and cesium (Cs) are essential to aquatic life (Ashraf et al., 2017). However, they can be toxic to human health and other life forms at higher concentrations. The purpose of this study is to determine the concentration distribution and contamination level of trace elements (barium (Ba), Br, cobalt (Co), Cs, hafnium (Hf), manganese (Mn), Rb, scandium ( $\mathrm{Sc}$ ) and $\mathrm{V})$ and the major element ferum (Fe) in Linggi estuary sediments using a modified degree of contamination $\left(m C_{d}\right)$ classification.

Identification of contamination level in the estuary sediments is important to gauge the level and effect of elemental pollution to benthic and other organisms. In addition, this study also provides crucial information to identify specific elements contributing to major pollutions in this area.

\section{Materials and Methods}

\section{Study Area and Sampling Procedure}

Surface sediment samples $(0-10 \mathrm{~cm})$ at the Linggi estuary were collected from 13 locations shown in Figure 1. The sediments were transferred into acid washed polyethylene bottles. Surface sediment samples were stored below $4^{\circ} \mathrm{C}$ in an icebox before being transported to the Malaysian Nuclear Agency laboratory in Bangi, Selangor, for further analysis. Surface sediment samples were dried at $60^{\circ} \mathrm{C}$ in an oven for one week or until the weight became constant. This was followed by pulverization using an agate mortar to less than $63 \mu \mathrm{m}$ mesh size.

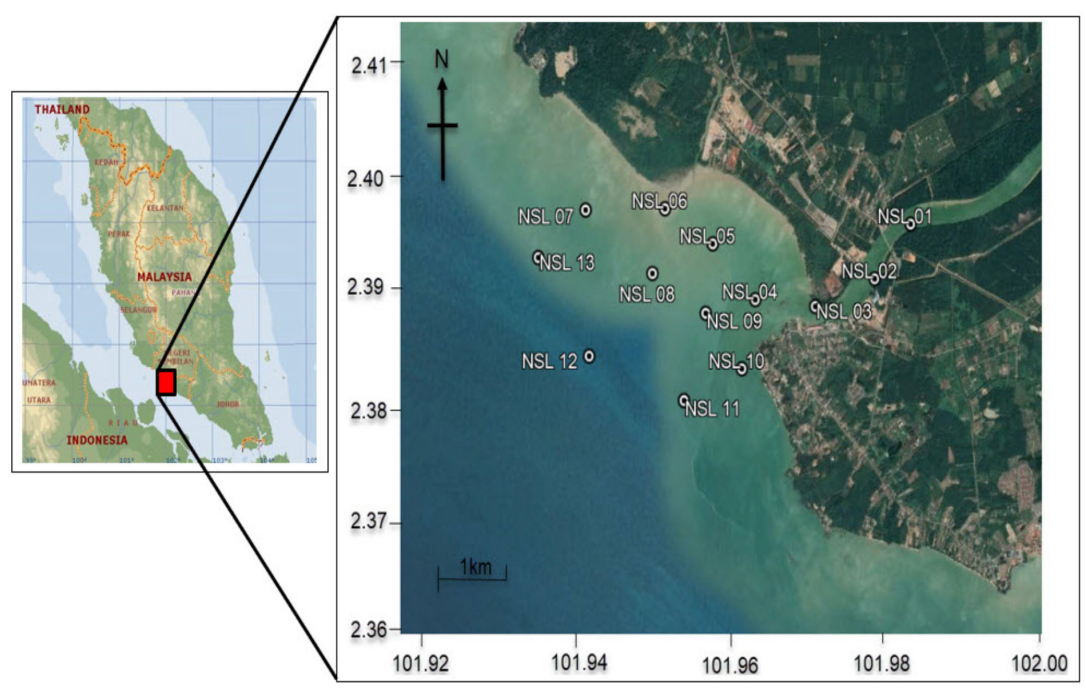

Figure 1: Study area and sampling sites of surface sediments at Linggi estuary 
Analysis of Surface Sediments by Neutron Activation Analysis (NAA) Technique

Approximately 150 to $200 \mathrm{mg}$ of homogenous powdered surface sediments were weighed and placed into polyethylene vials before irradiation at the PUSPATI TRIGA Research Reactor facility. The duplicate surface sediment samples, standard reference materials (SRM) (IAEA Soil7 and SL-1) and blank were irradiated on the rotary rack of the research reactor at $570 \mathrm{~kW}$. The surface sediment samples were irradiated for six hours, then allowed for decay process of two to four days and followed by one hour of counting. The counting process of the irradiated samples, SRM and blanks were performed using a gamma spectrometer. The trace elements in the surface sediment samples were identified according to their specific energies produced by gamma rays. The net peak areas (gamma ray intensity) of the trace elements in the surface sediment samples were compared to the SRM (IAEA Soil-7) as standard comparator for the purpose of concentration measurement. Calculation of trace element concentrations in surface sediment samples were performed according to Equation (1) (Joel et al., 2018; Elias et al., 2018a).

$$
C_{S m p}=C_{s t d} \times \frac{N A_{s m p}}{N A_{s t d}} \times \frac{M_{s t d}}{M_{s m p}}
$$

where: $C_{s m p}$ and $C_{s t d}$ are the trace element concentration in surface sediment sample and standard; $N A_{s m p}$ and $N A_{s t d}$ are the net peak area of trace element in surface sediment sample and standard; $M_{s m p}$ and $M_{\text {std }}$ are the surface sediment sample weight and standard weight, respectively.

\section{Modified Degree of Contamination $\left(m C_{d}\right)$}

Overaccumulation of trace elemental pollution in surface sediments would lead to adverse effects and pose potential ecological risks to the Linggi estuary ecosystem. The degree of contamination $\left(C_{d}\right)$ was one of the tools to assess the level of trace element contamination in rivers and marine sediments (Hakanson, 1980) i.e. to sort out which lakes/basins and substances should be given special attention. The work is based on the thesis that a sedimentological risk index for toxic substances in limnic systems should at least account for the four following requirements: 1. Eight species of pollutants (As, $\mathrm{Cu}, \mathrm{Cd}, \mathrm{Cr}, \mathrm{Hg}, \mathrm{Pb}, \mathrm{Zn}$ and $\mathrm{PCB}$ ) were proposed by Hakanson (1980) for degree of contamination $\left(C_{d}\right)$ measurement. The $C_{d}$ calculation was based on the contamination factor $\left(C_{f}\right)$ of each pollutant. The $C_{f}$ was the concentration value of trace element in sample divided by upper continental crust value (UCC), as shown in equation (2):

$$
C_{f}=\frac{M_{x}}{M_{b}}
$$

where: $M_{x}$ is the interest trace element concentration value in sample; $M_{b}$ is interest trace element of upper continental crust or background value.

The classification terminologies and calculation formula were based on restriction to the eight species of pollution. The sum of the eight species of pollution of $C_{f}$ values was defined as the overall $C_{d}$ in a sediment using equation (3) as proposed by Hakanson (1980) in equation 3.

$$
C_{d}=\sum_{i=1}^{8} C_{f}^{i}
$$

All eight species of pollution should be analysed to get the correct $C_{d}$ value. However, due to limitations (restriction to eight elements and substances) related to the calculation of $C_{d}$ proposed by Hakanson (1980), a modified degree of contamination $\left(m C_{d}\right)$ formulation was introduced by Abrahim \& Parker (2008). The formula for degree of contamination $\left(C_{d}\right)$ was generalised by defining the modified degree of contamination $\left(m C_{d}\right)$ as the sum of all the contamination factors $\left(C_{f}\right)$ divided by the number of analysed pollutants. The modified degree of contamination $\left(m C_{d}\right)$ formula is shown in equation (4):

$$
m C_{d}=\frac{\sum_{i=1}^{i=n} C_{f}^{i}}{n}
$$

where: $n, i$, and $C_{f}$ are the total number of elements, $i$ th element or pollutant, and contamination factor, respectively. The $m C_{d}$ 
formulation allowed incorporation of many elements (pollutants) and, therefore, posed no limit to the number of elements and organic pollutions for $\mathrm{mC}_{\mathrm{d}}$ measurement.

\section{Contour Maps}

The contour maps of the trace element concentration were generated using Surfer software version 11.0. Kriging interpolations were applied to illustrate the contour map of trace element concentrations in surface sediments of the Linggi estuary.

\section{Results and Discussion}

\section{Distribution Concentration and Sources of Trace Elements}

The concentrations of trace elements comprising $\mathrm{Ba}, \mathrm{Br}, \mathrm{Co}, \mathrm{Cs}, \mathrm{Hf}, \mathrm{Mn}, \mathrm{Rb}, \mathrm{Sc}$ and $\mathrm{V}$, and the major element $\mathrm{Fe}$ in Linggi estuary sediments and UCC values are tabulated in Table 1. The contour maps of trace and major elements are depicted in Figure 2(a) to 2(j). The average concentrations of $\mathrm{Br}, \mathrm{Cs}, \mathrm{Hf}, \mathrm{Rb}, \mathrm{Sc}$ and $\mathrm{V}$ were $46.9,2.2,1.7,1.3,1.5$, and 1.5 times higher compared to their UCC, respectively. This indicated that there were additional sources of $\mathrm{Br}, \mathrm{Hf}, \mathrm{Cs}, \mathrm{Rb}, \mathrm{Sc}$ and $\mathrm{V}$ pollutants originating from inland activities and waters of Linggi area.

The average $\mathrm{Br}$ concentration in the surface sediments of Linggi estuary and UCC were 75.1, and $1.6 \mathrm{mg} / \mathrm{kg}$, respectively. The concentrations of $\mathrm{Br}$ in soil varied from $<10$ to $130 \mathrm{mg} / \mathrm{kg}$ while $\mathrm{Br}$ concentration in the seawater was estimated at $<67.7$ to $3,000 \mathrm{mg} / \mathrm{L}$ (Cohen, 2014; Alina \& Szteke, 2015). Bromine salts and organic bromine substances were represented as $\mathrm{Br}$ and was one of the major substances in seawater. $\mathrm{Br}$ was produced by sea organisms as organic bromine (Lenntech, 2019). Br concentration in the deep-sea sediments off the state of Sabah in Borneo (deep sea) ranged from 36.9 to 188.3 $\mathrm{mg} / \mathrm{kg}$ (average $68.2 \mathrm{mg} / \mathrm{kg}$ ) (Ashraf et al., 2017). The $\mathrm{Br}$ source in the surface sediments of Linggi estuary could also originate from sea organisms.
The estimated mean concentration value of Hf content in mineral soil was $6.4 \mathrm{mg} / \mathrm{kg}$, which was within values of 2 to $20 \mathrm{mg} / \mathrm{kg}$. The average Hf concentration in the surface sediments of Linggi estuary and UCC was 10.0 and $5.8 \mathrm{mg} / \mathrm{kg}$, respectively. The relatively higher Hf concentration in the surface sediments of Linggi estuary was most likely contributed by sea organisms. The main areas with high concentrations of Hf were clearly indicated in locations NSL 8, NSL 10, NSL 11 and NSL 13, which were at the open sea, compared to NSL 01 and NSL 02 near the estuary as depicted in Figure 2(e).

There was also elevated $\mathrm{Hf}$ concentrations in Sabah sediments (deep sea) compared to average shale baseline value (Ashraf et al., 2017). This indicated that $\mathrm{Hf}$ pollution could also originate from marine life. Its presence in Sabah in sediments could be categorised from unpolluted to moderately polluted. However, other studies indicated that the sources of $\mathrm{Hf}$ could also be from sewage sludge and manufacturing waste from industries, such as metalworks, electrical and electronic factories and alloy smelters (Ashraf et al., 2017; Kabata-Pendias \& Szteke, 2015). The $\mathrm{Br}$ and Hf sources in the surface sediments of Linggi estuary mostly originated from the sea (sea salt, organism, bivalve, and marine life). The average concentration of $\mathrm{Br}$ in surface sediments of Linggi estuary is 75.1 $\mathrm{mg} / \mathrm{kg}$, which was higher compared to average concentration of $\mathrm{Br}$ in Linggi river sediments (14.6 mg/kg) (Elias, 2020). This probably indicated that the $\mathrm{Br}$ originated from the estuary, and it had travelled upstream. The study by Ashraf et al., (2017) also found the average concentration of $\mathrm{Br}$ in Sabah sediments to be at $68.17 \mathrm{mg} / \mathrm{kg}$, which was slightly comparable with the average concentration in Linggi estuary. The concentration of $\mathrm{Br}$ and $\mathrm{Hf}$ at sampling locations NSL 12 and 13, which were further in the open sea, were relatively higher compared to other locations adjacent to the river mouth as shown in Figures 2(b) and 2(e).

However, the average concentrations of $\mathrm{Cs}, \mathrm{Rb}, \mathrm{Sc}$, and $\mathrm{V}$ were relatively higher in 
the surface sediments of Linggi river, and they gradually decreased towards the estuary as shown in Figures 2(d), 2(g), 2(h) and 2(i). This indicated that the sources of $\mathrm{Cs}, \mathrm{Rb}, \mathrm{Sc}$, and $\mathrm{V}$ pollutants probably originated from upstream of the Linggi river basin.

The Cs content in various soil varied from $<1$ to $30 \mathrm{mg} / \mathrm{kg}$ (Kabata-Pendias \& Szteke, 2015), and since the element easily dissolves in water, it was, therefore, strongly adsorbed by clay minerals. The average concentration of $\mathrm{Cs}$ in the surface sediments of Linggi estuary was $12.6 \mathrm{mg} / \mathrm{kg}$, relatively higher than the UCC $(5.8 \mathrm{mg} / \mathrm{kg})$ and deep-sea sediments of a sea off Sabah. The Cs values measured in the Sabah ocean (deep sea) ranged from 1.85 to 6.18 $\mathrm{mg} / \mathrm{kg}$, with an average of $3.42 \mathrm{mg} / \mathrm{kg}$ (Ashraf et al., 2017). This clearly indicated that Cs sources in Linggi estuary originated upstream as depicted in Figure 2(d). The pollution likely came from an area where the river flowed past vehicle workshops and electroplating factories in Seremban (Elias, et al., 2018a). After the workshops and factories in Seremban, the river also flowed past the Senawang industrial estate, which hosted several chemical, electrical and lubricant factories (Nather Khan \& Lim, 1991). These industries may be the contributors of Cs pollution, which would be carried by the river to the Linggi estuary.

$\mathrm{Rb}$ concentration in the earth's crust ranged from 90 to $110 \mathrm{mg} / \mathrm{kg}$ (Kabata-Pendias \& Szteke, 2015). There was approximately $<100$ to $200 \mathrm{mg} / \mathrm{kg}$ of $\mathrm{Rb}$ in igneous rocks, and $<120$ to $200 \mathrm{mg} / \mathrm{kg}$ in sedimentary argillaceous rocks (Kabata-Pendias \& Szteke, 2015). Geogenic sources of $\mathrm{Rb}$ usually included land clearing, soil, riverbank and coastal erosion, and the industrial sources such as glass dust, electronic tubes, ceramic and photocell manufacturing (Ashraf et al., 2017). The man-made causes of $\mathrm{Rb}$ pollution were mainly sewage sludge and phosphate fertilizers from farming (KabataPendias \& Szteke, 2015). The average Rb concentration in sewage sludge and phosphate fertilizers were $<100.0$ and $5 \mathrm{mg} / \mathrm{kg}$, respectively. The average concentrations of $\mathrm{Rb}$ in the surface sediments of Linggi estuary and UCC were 146 and $110 \mathrm{mg} / \mathrm{kg}$, respectively. These showed that the average concentrations of $\mathrm{Rb}$ in the estuary surface sediments were slightly comparable to $\mathrm{UCC}$, indicating that the possible sources of $\mathrm{Rb}$ was from geogenic processes.

The average $\mathrm{Sc}$ concentrations in the surface sediments of Linggi estuary and UCC were 10.6 and $7.0 \mathrm{mg} / \mathrm{kg}$, respectively. However, Sc content values ranged from 0.8 to $28 \mathrm{mg} / \mathrm{kg}$, with an average of $12.0 \mathrm{mg} / \mathrm{kg}$ (worldwide). The Sc sources were mainly derived from granitic and volcanic rocks (geogenic) that underwent terrestrial runoff and erosion. The amount of Sc in phosphate fertilizer, mostly found in agricultural soils, could be measured to about $40 \mathrm{mg} / \mathrm{kg}$ (Kabata-Pendias \& Szteke, 2015). The sources of Sc in surface sediments of Linggi estuary were most likely from granitic and geogenic processes because the average concentration of Sc was comparable to the UCC value.

Vanadium concentrations ranged from 70 to $320 \mathrm{mg} / \mathrm{kg}$, with an average of $130.0 \mathrm{mg} /$ $\mathrm{kg}$ (worldwide) in soil. Its concentration in the surface sediments of Linggi estuary and UCC values were 80.5 and $53.0 \mathrm{mg} / \mathrm{kg}$, respectively. Vanadium concentration in argillaceous sediments might be up to $130 \mathrm{mg} / \mathrm{kg}$, whereas it was $60 \mathrm{mg} / \mathrm{kg}$ in coal and 1,300 mg/kg in crude oil. The same metal's concentrations in sediments of Scheldt estuary in the Netherlands ranged from 60 to $116 \mathrm{mg} / \mathrm{kg}$ (average $95 \mathrm{mg}$ / kg) (Zwolsman \& Eck, 1999). In the sediments of Xinjiang river, China, it was between 43.9 and $210 \mathrm{mg} / \mathrm{kg}$ (average $117 \mathrm{mg} / \mathrm{kg}$ ) (Chai et al., 2016). And in South China Sea sediments, its range was between 0.03 and $148 \mathrm{mg} / \mathrm{kg}$ (average $78 \mathrm{mg} / \mathrm{kg}$ ) (Zhu et al., 2011). Vanadium sources mainly originated from crude petroleum, lubricants, coal combustion, steel alloys and vehicle emission (Kabata-Pendias \& Szteke, 2015). The possible sources of vanadium in the surface sediments of Linggi estuary were likely from the Seremban and Senawang industrial parks, where vehicle workshops and industrial activities were located (Elias et al., 2018b). 
Meanwhile, the average concentrations of $\mathrm{Ba}, \mathrm{Co}, \mathrm{Mn}$, and $\mathrm{Fe}$ were less than the UCC values of the respective elements. The concentrations of $\mathrm{Ba}, \mathrm{Co}$ and $\mathrm{Mn}$ were relatively lower than the corresponding UCC values in all locations, whereas three locations showed relatively higher $\mathrm{Fe}$ concentration than the UCC value (Table 1). However, the average Fe concentration shown was relatively lower value than UCC. This indicated that there were no enrichment of $\mathrm{Ba}, \mathrm{Co}, \mathrm{Mn}$ and $\mathrm{Fe}$ pollutants in the surface sediments of Linggi estuary.

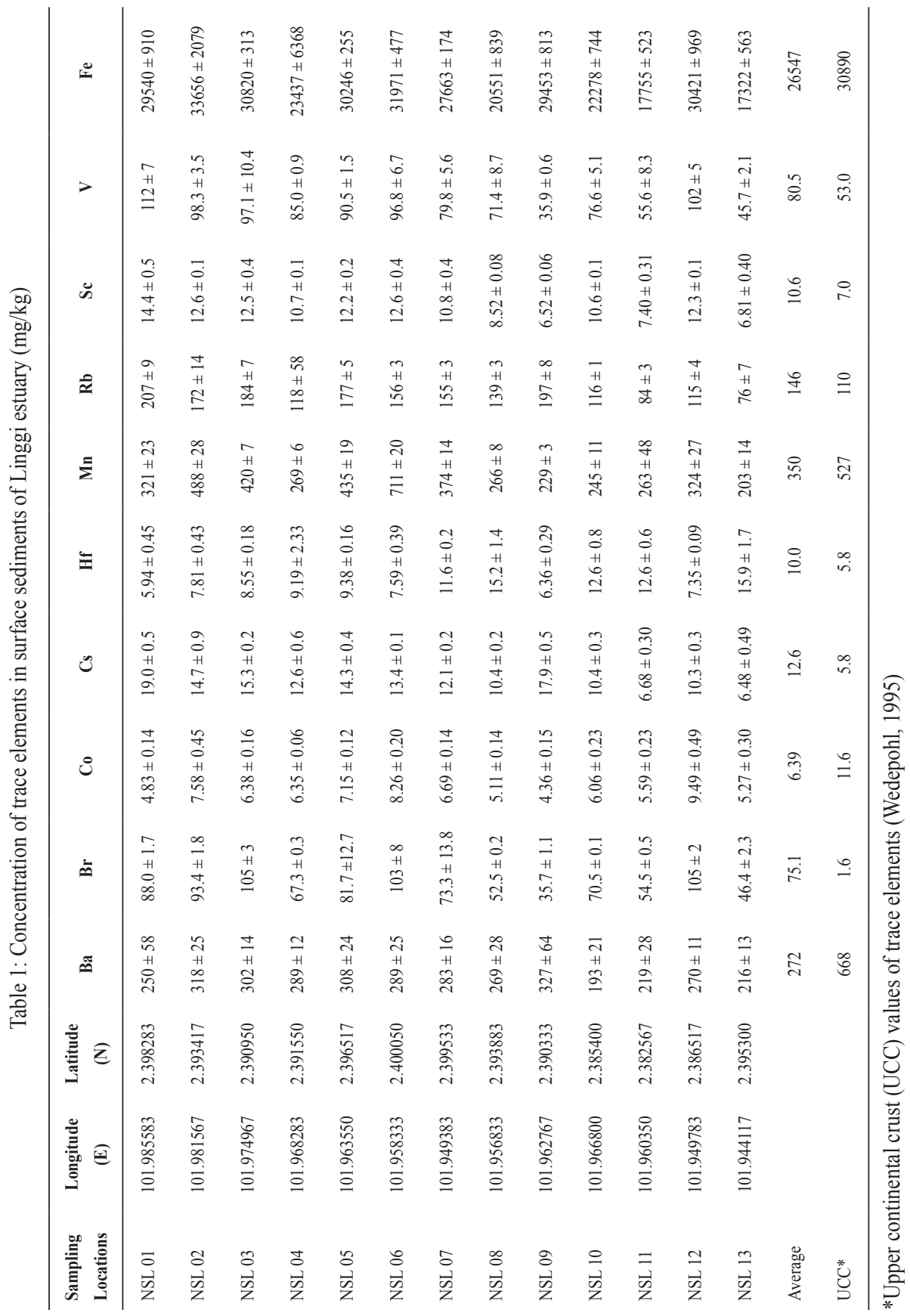




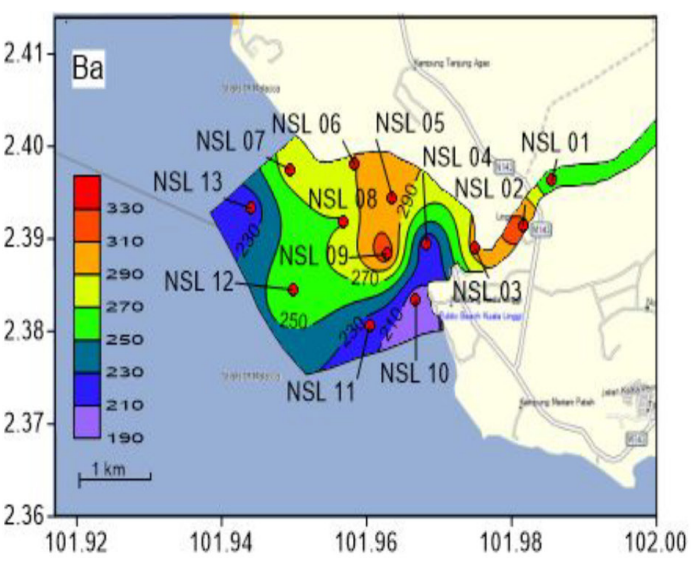

(a)

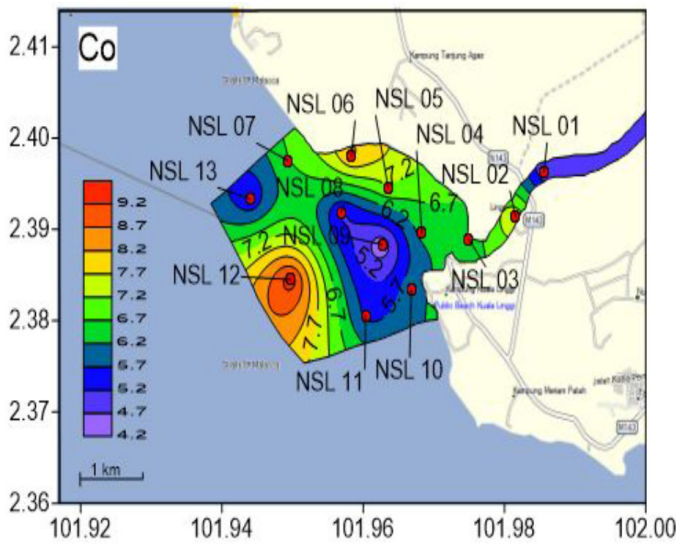

(c)

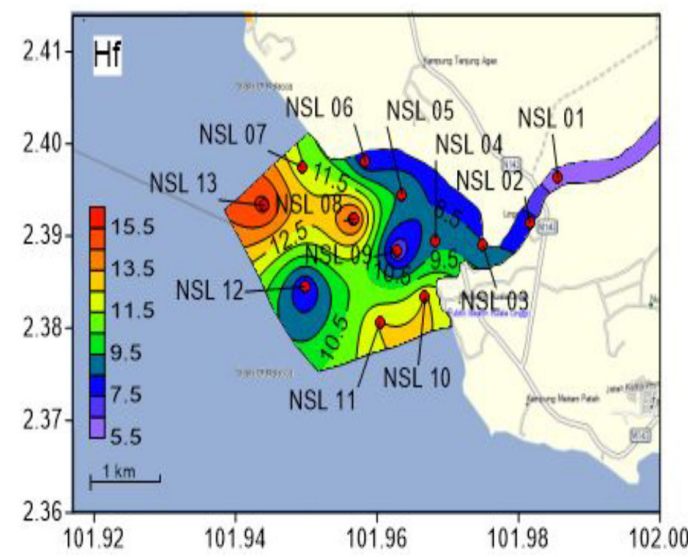

(e)

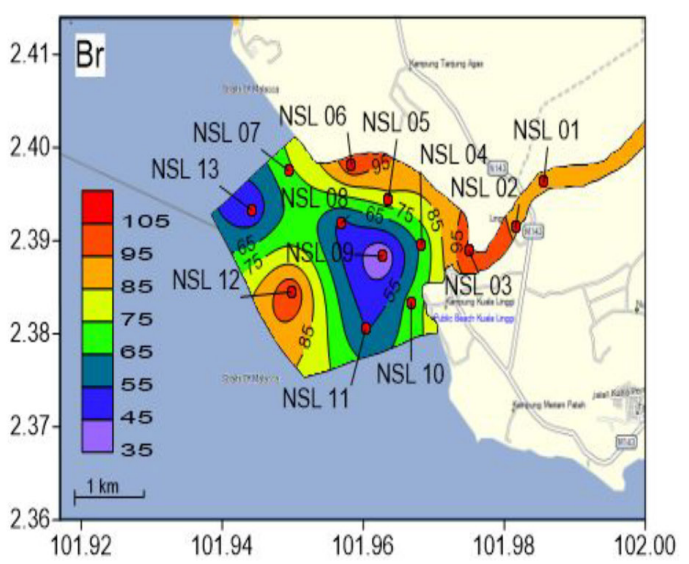

(b)

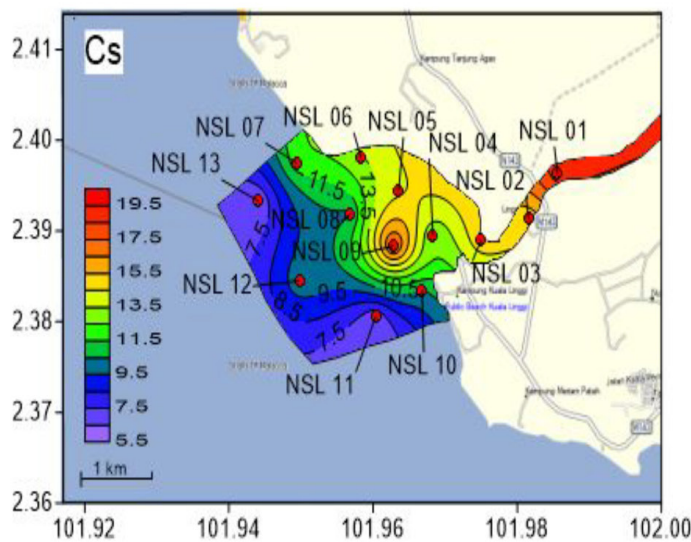

(d)

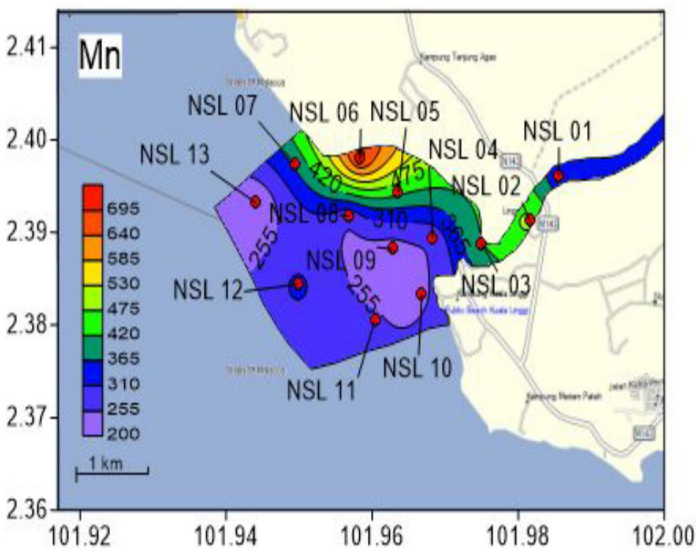

(f) 


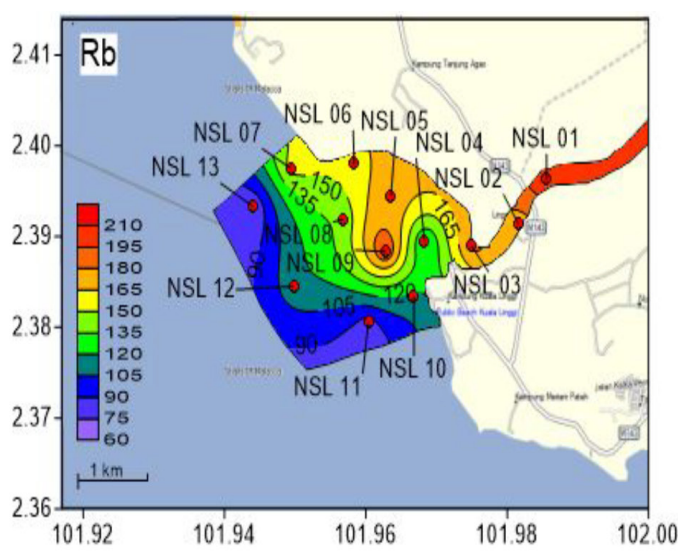

$(\mathrm{g})$

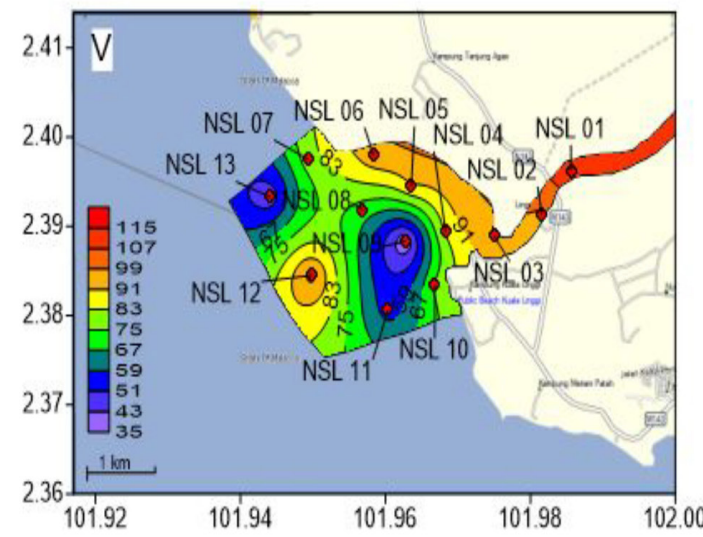

(i)

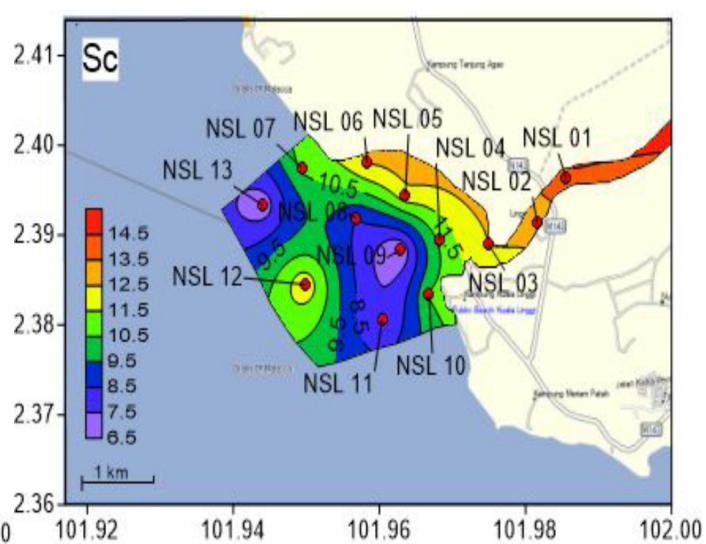

(h)

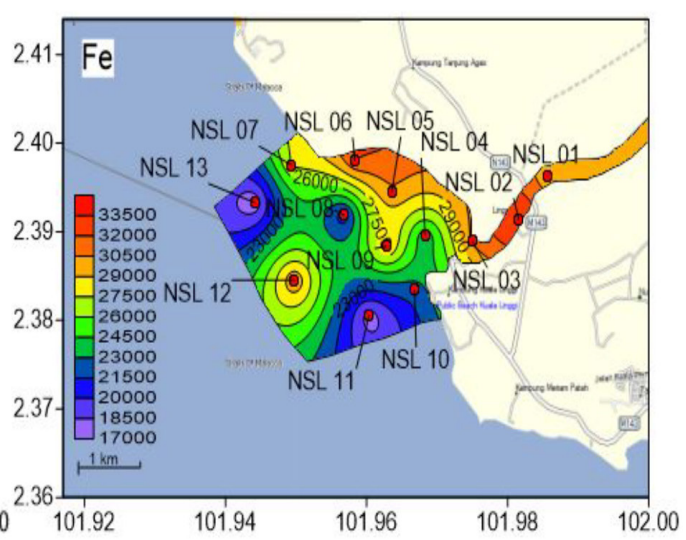

(j)

Figure 2: Contour maps of trace element concentrations in surface sediments of Linggi estuary

\section{Modified Degree of Contamination ( $\left.m C_{d d}\right)$}

The modified degree of contamination $\left(m C_{d}\right)$ classification had been widely used in assessing sediment contamination in river, estuary and marine ecosystems (Abrahim \& Parker, 2008; Rahman et al., 2012; Jamshidi-zanjani \& Saeedi, 2013; Likuku et al., 2013; Pejman et al., 2015; Sivakumar et al., 2016; Chai et al., 2016; Ashraf et al., 2017; Jiang et al., 2018). The $m C_{d}$ classification description in sediments and their gradient values were simplified as follows: $m C_{d}$ $<1.5$ (nil to very low); $1.5 \leq m C_{d}<2$ (low); 2 $\leq m C_{d}<4$ (moderate); $4 \leq m C_{d}<8$ (high); $8 \leq$ $m C_{d}<16$ (very high); $16 \leq m C_{d}<32$ (extremely high); and $m C_{d} \geq 32$ (ultra-high degree of contamination) (Abrahim \& Parker, 2008).

The contamination factor $\left(C_{f}\right)$ showed that bromine was the significant contributor to $m C_{d}$ values, ranging from 22.34 to 65.53 . The $C_{f}$ values for $\mathrm{Cs}, \mathrm{Hf}, \mathrm{Rb}, \mathrm{Sc}$, and $\mathrm{V}$ were greater than one in most of the sampling locations as shown in Table 2, which also contributed to the values. Two sampling locations (NSL 09 and NSL 13) could be categorised as having moderately $m C_{d}$, while all others were experiencing a highly modified degree of contamination. NSL 09 showed the lowest $m C_{d}$ values (3.22) while NSL 03 had the highest at 7.77 as tabulated in Table 2. 
The high $m C_{d}$ value at NSL 03 was 09 (22.34). Other elements, such as Cs, Hf, Rb, due to the highest contamination factor $\left(C_{f}\right) \quad \mathrm{Sc}$ and $\mathrm{V}$, also significantly contributed to the values, with major contributions from Br. The $m C_{d}$ values at NSL 03. Overall, the $m C_{d}$ values contamination factor $\left(C_{f}\right)$ of $\mathrm{Br}$ at NSL 03 of surface sediments of Linggi estuary ranged (65.53) was three times higher compared to NSL from moderate to high degree of contamination.

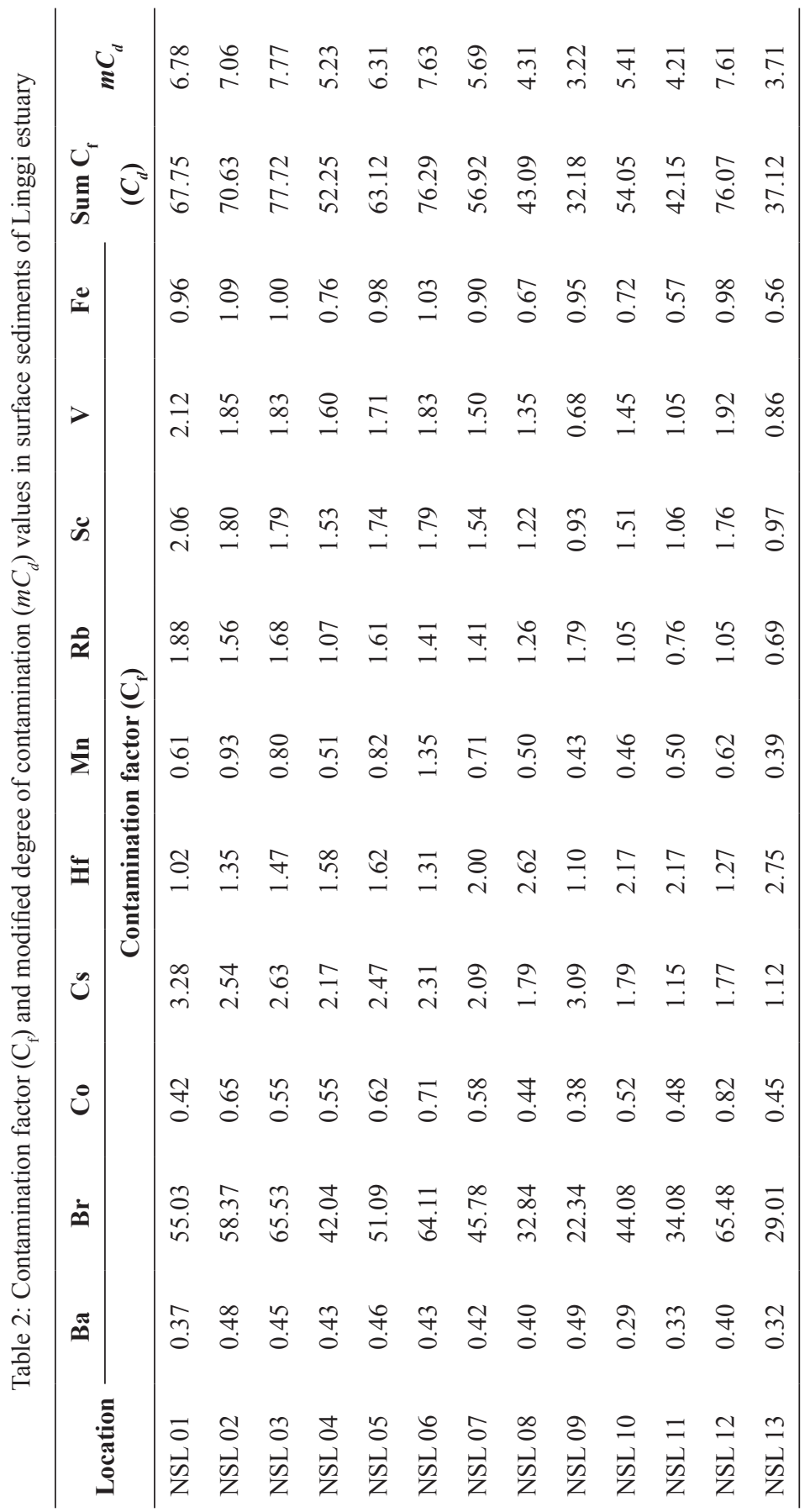




\section{Conclusion}

The average concentration values of trace elements (Br, Cs, Hf, Rb, Sc, and V) in the surface sediments of Linggi estuary were relatively higher compared to UCC values, whereas $\mathrm{Ba}, \mathrm{Co}, \mathrm{Mn}$, and $\mathrm{Fe}$ showed relatively lower average. This indicated that $\mathrm{Br}, \mathrm{Cs}, \mathrm{Hf}, \mathrm{Rb}$, $\mathrm{Sc}$, and $\mathrm{V}$ showed enrichment of concentration in the estuary's surface sediments. The sources of $\mathrm{Br}$ and $\mathrm{Hf}$ possibly originated from seawater and marine life. The elements of Cs and V came from anthropogenic activities, such as vehicle workshops and industrial activities (electronic and electroplating), and elements of $\mathrm{Rb}$ and $\mathrm{Sc}$ originated from geogenic processes, such as erosion, weathering and terrestrial runoff.

$\mathrm{Br}, \mathrm{Cs}, \mathrm{Hf}, \mathrm{Rb}, \mathrm{Sc}$, and $\mathrm{V}$ were the major contributors of the contamination factor $\left(C_{f}\right)$ in Linggi estuary. Results of $m C_{d}$ showed that trace element contamination in surface sediments of Linggi estuary could be categorised as moderate to highly modified degree of contamination.

\section{Acknowledgements}

This project was supported by Ministry of Science, Technology and Innovation (MOSTI), through research grant 04-03-01-SF0142. The authors like to thank Green Technology \& Sustainable Development, Community of Research (CORE), Universiti Teknologi MARA (UiTM), for their technical assistance.

\section{References}

Abrahim, G. M. S., \& Parker, R. J. (2008). Assessment of heavy metal enrichment factors and the degree of contamination in marine sediments from Tamaki Estuary, Auckland, New Zealand. Environmental Monitoring and Assessment, 136(1-3), 227238.

Ashraf, A., Saion, E., Gharibshahi, E., Kamari, H. M., Yap, C. K., Hamzah, M. S., \& Elias, M. S. (2017). Distribution of trace elements in core marine sediments of coastal east Malaysia by instrumental neutron activation analysis. Applied Radiation and Isotopes, 122, 96-105. https://doi.org/10.1016/j. apradiso.2017.01.006.

Chai, L., Li, H., Yang, Z., Min, X., Liao, Q., Liu, Y., ... Xu, J. (2016). Heavy metals and metalloids in the surface sediments of the Xiangjiang River, Hunan, China: distribution, contamination, and ecological risk assessment. Environmental Science and Pollution Research, 24(1), 874-885. https:// doi.org/10.1007/s11356-016-7872-x.

Cohen, D. (2014). Notes for IAEA participant: Air pollution Workshop, Seibersdorf, Vienna. 22-26 Nov 2014. Australian Nuclear Science and Technology Organisation Australia.

DOE. (2006). Malaysia Environmental Quality Report 2010. Malaysia Environmental Quality Report Annual Report, 2006, 1-72. https://doi.org/ISBN 0127-6433.

Elias, M. S. (2020). Study of Elemental and Stable Isotope Ratio as a Marker for Source Identification of Pollution in Sediment of Linggi River. Thesis. Universiti Teknologi MARA (UiTM).

Elias, M. S., Ibrahim, S., Samuding, K., Rahman, A. R., \& Hashim, A. (2018a). The sources and ecological risk assessment of elemental pollution in sediment of Linggi estuary, Malaysia. Marine Pollution Bulletin, 137, 646-655.

Elias, M. S., Ibrahim, S., Samuding, K., Rahman, S., Wo, Y. M., \& Daung, J. A. D. (2018b). Multivariate analysis for source identification of pollution in sediment of Linggi River, Malaysia. Environmental Monitoring and Assessment, 190(4), 257 (1-16).

Hakanson, L. (1980). An ecological risk index for aquatic pollution control. A sedimentological approach. Water Research, 14(8), 975-1001.

Jamshidi-zanjani, A., \& Saeedi, M. (2013). Metal pollution assessment and multivariate analysis in sediment of Anzali international wetland. Environmental Earth Science, 70,1791-1808. https://doi.org/10.1007/ s12665-013-2267-5. 
Jiang, Q., He, J., Ye, G., \& Christakos, G. (2018). Heavy metal contamination assessment of surface sediments of the East Zhejiang coastal area during 2012 - 2015. Ecotoxicology and Environmental Safety, 163, 444-455.

Joel, E. S., Maxwell, O., Adewoyin, O. O., EhiEromosele, C. O., Embong, Z., \& Oyawoye, F. (2018). Assessment of natural radioactivity in various commercial tiles used for building purposes in Nigeria. Methods X, 5, 8-19.

Kabata-Pendias, A., \& Szteke, B. (2015). Trace Elements in Abiotic and Biotic Environments. CRC Press, Taylor \& Francis Group. 6000 Broken Sound Parkway NW, Suite 300 Boca Raton, FL 33487-2742. https://doi. org/10.1201/b18198.

Lenntech. (2019). http://www.lenntech. $\mathrm{com} / \mathrm{processes} / \mathrm{disinfection/ \textrm {chemical } /}$ disinfectants-bromine.htm.

Likuku, A. S., Mmolawa, K. B., \& Gaboutloeloe, G. K. (2013). Assessment of heavy metal enrichment and degree of contamination around the copper-nickel mine in the Selebi Phikwe Region, Eastern Botswana. Environment and Ecology Research, 1(2): $32-40$.

Liu, Q., Wang, F., Meng, F., Jiang, L., Li, G., \& Zhou, R. (2018). Assessment of metal contamination in estuarine surface sediments from Dongying City, China: Use of a modified ecological risk index. Marine Pollution Bulletin, 126: 293-303.

Looi, L. J., Aris, A. Z., Wan Johari, W. L., Md. Yusoff, F., \& Hashim, Z. (2013). Baseline metals pollution profile of tropical estuaries and coastal waters of the Straits of Malacca. Marine Pollution Bulletin, 74(1), 471-476.

Nather Khan, I. S. A., \& Lim, R. P. (1991). Distribution of metals in the linggi river basin, malaysia, with reference to pollution. Marine and Freshwater Research, 42(4), 439-445. https://doi.org/10.1071/MF9910435.

Pejman, A., Nabi, G., \& Ardestani, M. (2015). A new index for assessing heavy metals contamination in sediments: A case study. Ecological Indicators, 58, 365-373.

Rahman, S. H., Khanam, D., Adyel, T. M., Islam, M. S., Ahsan, M. A., \& Akbor, M. A. (2012). Assessment of Heavy Metal Contamination of Agricultural Soil around Dhaka Export Processing Zone (DEPZ), Bangladesh: Implication of Seasonal Variation and Indices. Applied Sciences, 2, 584-601. https://doi.org/10.3390/app2030584.

Rezaee, K., Saion, E. B., Wood, A. K., \& Abdi, M. R. (2010). Rare earth elements determination and distribution patterns in surface marine sediments of the South China Sea by INAA. Journal of Radioanalytical and Nuclear Chemistry, 283(3), 823-829.

Sivakumar, S., Chandrasekaran, A., Balaji, G., \& Ravisankar, R. (2016). Assessment of Heavy Metal Enrichment and the Degree of Contamination in Coastal Sediment from South East Coast of Tamilnadu , India. Journal of Heavy Metal Toxicity and Diseases, 1(2): 1-8. https://doi. org/10.21767/2473-6457.100011.

Wedepohl, K. H. (1995). The composition of the continental crust. Geochimica et Cosmochimica Acta, 59(7), 1217-1232.

Yap, C. K., Edward, F. B., \& Tan, S. G. (2010). Heavy Metal Conterations $(\mathrm{Cu}, \mathrm{Pb}, \mathrm{Ni}$ and $\mathrm{Zn}$ ) in the surface sediments from a semienclosed intertidal water, the Johore Straits: Monitoring data for future reference. Journal of Sustainability and Management, 5(2), 4457.

Zhu, L., Xu, J., Wang, F., \& Lee, B. (2011). An assessment of selected heavy metal contamination in the surface sediments from the South China Sea before 1998. Journal of Geochemical Exploration, 108(1), 1-14.

Zwolsman, J. J. G., \& Eck, G. T. M. Van. (1999). Geochemistry of major elements and trace metals in suspended matter of the Scheldt estuary, southwest Netherlands. Marine Chemistry, 66, 91-111. 